\title{
Removal of large sized ovarian cysts by potentized homeopathic remedies: a myth or a dependable alternative option
}

\begin{abstract}
Removal of large sized ovarian cysts by homeopathic treatment is generally not considered as a dependable option vis-a-vis removal via surgery. In this communication, we present three authentic cases of successful removal of big sized ovarian cysts by administration of a single potentized homeopathic remedy, Apis mellifica, selected on the basis of totality of symptoms, and authenticated with the aid of ultrasonographic as well as hormonal studies.
\end{abstract}

Keywords: human, ovarian cyst removal, homeopathy, apis mellifica, ultrasonography, hormones
Volume 3 Issue 5 - 2016

\author{
Debarsi Das,' 'Asmita Samadder,'2 Saroj \\ Kumar Kayal,' Anisur Rahman Khuda-Bukhs ${ }^{3}$ \\ 'Mahesh Bhattacharyya Homeopathic Medical College and \\ Hospital, India \\ 2Department of Zoology, Dum Dum Motijheel College, India \\ ${ }^{3}$ UGC Emeritus Fellow, Kalyani University, India
}

\begin{abstract}
Correspondence: Anisur Rahman Khuda-Bukhsh, UGC Emeritus Fellow at University of Kalyani, B-2/325, Kalyani, Husn-Ara Manzil, Kalyani-74I 235, West Bengal, India, Tel 919331040032,Email proof_arkb@yahoo.co.in
\end{abstract}

Received: April 19, 2016 | Published: May 12, 2016
Abbreviations: $\mu \mathrm{g}$, microgram; AM, after medicine; BM, before medicine; DHEAS, dehydroepiandrosterone sulphate; dl, decilitre; E2, estradiol; F, fasting; FSH, follicle stimulating hormone; IU, international unit; LH, leutinizing hormones; mg, milligram; ml, millilitre; ng, nanogram; pg, picogram; PP, post prandial;

\section{Introduction}

An ovarian cyst can be defined as a collection of fluid surrounded by a very thin wall within an ovary; any follicle larger than about two centimetres is termed as an ovarian cyst, ${ }^{1}$ and they vary in size from a pea (small) to much larger size, almost that of an orange. Although they are mostly found in women of reproductive age and most of them are harmless or benign in nature they are reported occasionally to cause severe pain in the abdomen with menstrual irregularities and cause excessive bleeding. In such cases when the cyst size is causing concern not only for its increasing size but also for causing certain undesirable symptoms like dull aching or sudden sharp stitching pain in lower abdomen, pain during coition or even during bowel movements it has to be treated with some seriousness; it also sometimes gives a full or bloated feeling after eating a small meal and also produces a constant nauseating or vomiting tendency. If patients with these symptoms visit an orthodox medical practitioner or surgeon, they are generally advised for surgical intervention to save the patient from further unwanted sufferings. There is a lack of confidence in both the patients and also in less experienced homeopathic practitioners to decide, particularly when the cyst size is alarming, if the patient should undergo surgical intervention or can undertake homeopathic course of treatment. Lack of many published case reports on successful removal of large sized ovarian cysts indicating efficacy of specific homeopathic remedies without necessity of any surgical intervention, is the main cause of such a dilemma. Thus, there is a need for documentation of cases of successful removal of cysts, preferably by well selected single homeopathic remedy. Practitioners of orthodox medicines or surgeons also find some cases where even after surgical intervention, there may be development of fast growing tissue with the risk of leading it to cancer at the site of surgical incision., ${ }^{2,3}$ However, such cases are relatively few.
For the treatment of large ovarian single cysts, homoeopathic remedies are selected by taking into consideration totality of symptoms and based further on individualization of the particular patient in consultation with the reportorial rubrics ${ }^{4}$ (Table 1). Several drugs are effectively used in different patients depending on their totality of symptoms and particularly taking into consideration some "repertorial guiding symptoms" ${ }^{-6}$ (Table 1); the most commonly used drugs are Apis mellifica, Belladonna, Lachesis, Arsenicum alb, Thuja etc. ${ }^{4}$ (Table 1), of which Apis mel patients have typical symptoms as mentioned in Allen ${ }^{5}$ and Boreicke ${ }^{6}$ which can clearly distinguish them from that of the other drugs.

The patients with ovarian cysts generally manifest some typical symptoms like-feeling of congestion in the abdomen with right- or left-sided soreness in the inguinal region; have a feeling of stinging, burning and sore sensation. ${ }^{4-6}$ Along with these, sometimes, they report complaint of tightness of the chest with an urge to urinate, occasionally with burning sensation in urine, bearing down sensation as if menses were to appear, sensitive and tenderness over abdomen. Patients experience amelioration of these symptoms by cold water application and warmth often aggravates. In course of our extensive studies being carried out on patients with ovarian single cysts and multiple cysts, ${ }^{7,8}$ we are reporting here three cases of patients, who presented typical guiding symptoms that agreed well and justified with the selection of Apis mellifica as the single remedy without any ambiguity.

\section{Case presentation}

\section{Case study}

The common general symptoms of all the three patients as well as minor individual deviations have been mentioned in Tables 2-4 for the three patients. All of them were confirmed cases of bearing large single cysts located in right ovary. They visited the clinic mainly with a complaint of nagging pain in the right abdominal region and some menstrual problem. They were first advised to perform trans-ovarian ultra-sonography (USG) at the earliest which they complied with. USG reports confirmed presence of large sized cysts in all of them. 


\section{Treatment}

The detailed initial symptoms of the three patients, who visited the clinic on different dates, their prescriptions made, and their gradual symptomatic amelioration as well as hormonal data has been summarized in Tables 2-5 and Figures 1-7. The USG images of the respective patients have been provided showing the status before the beginning of homeopathic drug administration and also after the treatment was complete (Figures 1-6), for patients 1-3, respectively. For statistical analysis of the hormonal data, standard student " $t$ " tests were performed before and after administration of the homeopathic medicines.

Table I Kent's Repertory with chapter, page number and concerned rubric indicating Apis mel to be the first drug of choice for all three patients

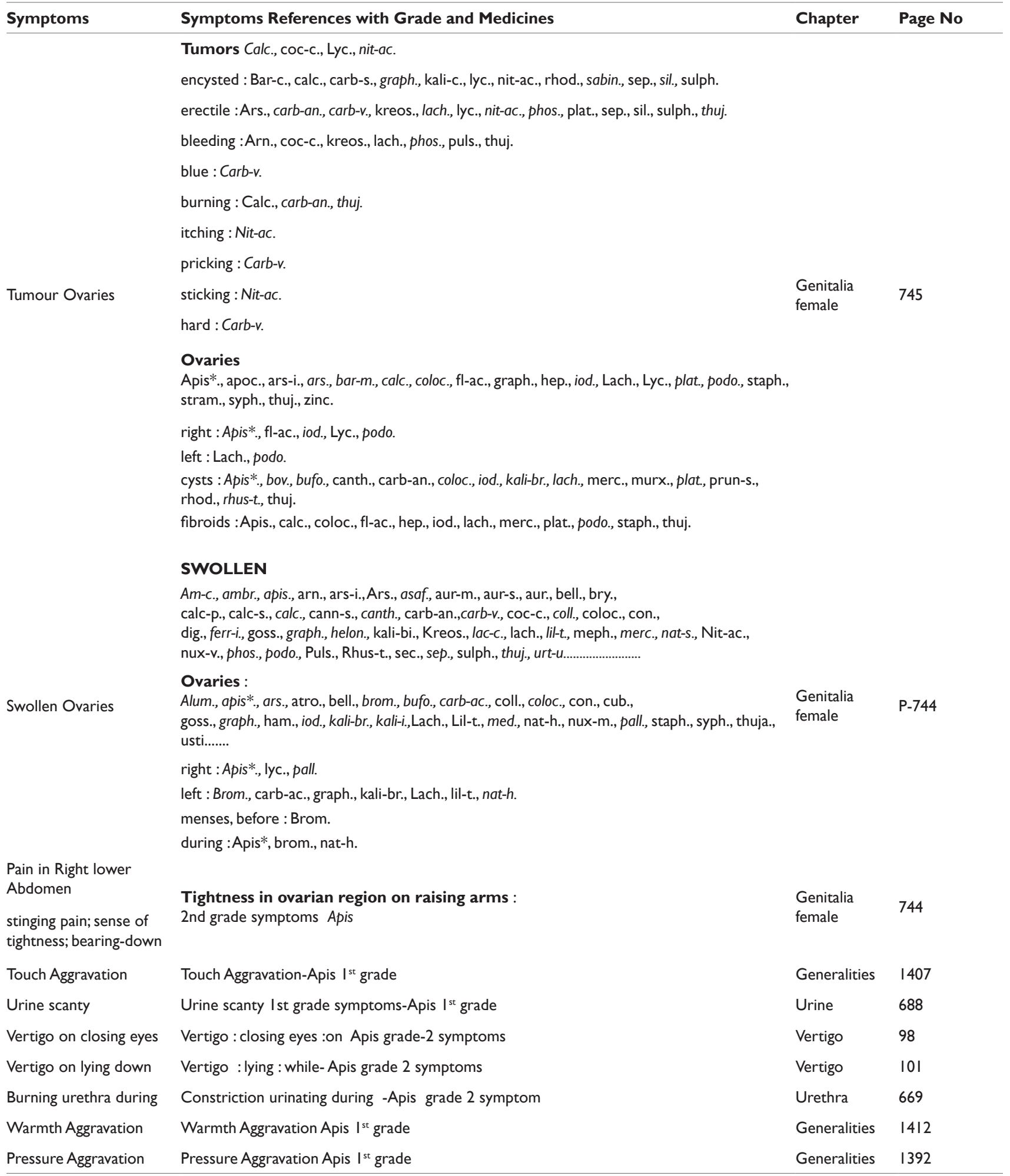


Table 2 Details of symptoms, prescriptions, and improvements of the Patient No. I (Age: I9 years, unmarried)

\begin{tabular}{|c|c|c|c|c|}
\hline Visit & Symptoms & $\begin{array}{l}\text { Medicine } \\
\text { Given }\end{array}$ & $\begin{array}{l}\text { Period of taking } \\
\text { medicine }\end{array}$ & $\begin{array}{l}\text { Advised to } \\
\text { come after }\end{array}$ \\
\hline $\begin{array}{l}\text { First Visit } \\
18.04 .2015\end{array}$ & $\begin{array}{l}\text { USG showed mild diffuse fatty change of liver, bulky uterus, complex cyst } \\
\text { in right ovary, } \\
\text { size- } 89.1 \mathrm{mmX} 56 . \mathrm{mm} \\
\text { General symptoms: Sensation of stiffness and as of something torn off in } \\
\text { the interior of the body; abdomen sore and stinging pains, pain in right } \\
\text { lower abdomen; menses scanty, painful, dysmenorrhœa, with heaviness } \\
\text { of lower abdomen; sense of tightness; bearing-down, as if menses were } \\
\text { to appear; tenderness felt at perineum region; leucorrhoea at onset of } \\
\text { menstruation; much prostration, and cannot concentrate her mind when } \\
\text { attempting to read or study even a story book; vertigo on lying down or } \\
\text { closing eyes; burning and soreness when urinating, pain and urine scanty. } \\
\text { Modalities: Aggravated by warmth, touch and pressure; feels better in } \\
\text { open air, and cold bathing; }\end{array}$ & Apis 30 & $\begin{array}{l}\text { Twice daily for } 10 \text { days } \\
\text { (at least } 45 \text { minutes to } \\
\text { I hr before or after any } \\
\text { food) and Placebo for } \\
\text { another } 20 \text { days }\end{array}$ & $\begin{array}{l}\text { Advised to report } \\
\text { after } 30 \text { days }\end{array}$ \\
\hline 20.05.20I5 & Improvement of her pain in the abdomen. & Placebo & I month & I month \\
\hline 19.06 .2015 & $\begin{array}{l}\text { Feeling of weakness gradually improving; urinary symptoms also improved } \\
\text { considerably. }\end{array}$ & Placebo & I month & $\begin{array}{l}\text { Advised to report } \\
\text { after } 30 \text { days }\end{array}$ \\
\hline 22.07.20I5 & $\begin{array}{l}\text { Once experienced moderate (bearable) pain with burning feeling in the } \\
\text { urethra, in Ist week of July20I5. }\end{array}$ & Apis 200 & $\begin{array}{l}\text { Twice daily for } 2 \text { days, } \\
\text { with placebo for the } \\
\text { rest } 28 \text { days }\end{array}$ & I month \\
\hline 19.08.2015 & Felt mild pain in the abdomen once only, otherwise doing well. & placebo & I month & I month \\
\hline 23.09.20I5 & $\begin{array}{l}\text { Status of patient further improved in respect of all symptoms and she } \\
\text { continued to feel good with regular and normal menstruation. }\end{array}$ & placebo & I month & $\begin{array}{l}\text { Advised to report } \\
\text { after } 30 \text { days }\end{array}$ \\
\hline 20.10 .2015 & $\begin{array}{l}\text { Reported bleeding in last cycle quite profuse and pain recurred. Once } \\
\text { urethral burning felt. }\end{array}$ & Apis I M & $\begin{array}{l}2 \text { doses for } 2 \text { days, } \\
\text { once daily, rest } 28 \text { days } \\
\text { placebo }\end{array}$ & $\begin{array}{l}\text { Advised to report } \\
\text { after } 30 \text { days }\end{array}$ \\
\hline 18.11 .2015 & Reported remarkable improvement & Placebo & $\begin{array}{l}2 \text { doses, once daily for } \\
2 \text { days } \\
\text { Placebo for Imonth }\end{array}$ & $\begin{array}{l}\text { I month, Advised } \\
\text { for another USG. }\end{array}$ \\
\hline $\begin{array}{l}\text { Final visit } \\
\text { 18.12.20|5 }\end{array}$ & No complaints, the patient was doing well and has not reported so far. & $\begin{array}{l}\text { No medicine } \\
\text { prescribed }\end{array}$ & $\begin{array}{l}\text { Advised to report if } \\
\text { any problem recurs in } \\
\text { future }\end{array}$ & $\begin{array}{l}\text { USG showed no } \\
\text { abnormality. } \\
\text { (Figure I\& 2) }\end{array}$ \\
\hline
\end{tabular}

Table 3 Details of symptoms, prescriptions, and improvements of the Patient No. 2 (Age 26, unmarried)

\begin{tabular}{|c|c|c|c|c|}
\hline Visit & Symptoms & $\begin{array}{l}\text { Medicine } \\
\text { Given }\end{array}$ & $\begin{array}{l}\text { Period of taking } \\
\text { Medicine }\end{array}$ & $\begin{array}{l}\text { Advised to } \\
\text { Come after }\end{array}$ \\
\hline $\begin{array}{l}\text { First Visit } \\
12.03 .2014\end{array}$ & $\begin{array}{l}\text { I I/3/20 I } 4 \text { Bulky right ovary and presence of right ovarian cyst } \\
\text { [ } 47 \mathrm{~mm} \times 35 \mathrm{~mm}] \\
\text { Pain right lower abdomen, menses alternately scanty and profuse, } \\
\text { painful, with heaviness of lower abdomen, stinging pain; sense } \\
\text { of tightness; bearing-down, as if menses were to appear; abdomen } \\
\text { sore and tenderness felt at perineum region; leucorrhoea at onset } \\
\text { of menstruation, vertigo on closing eyes; burning and soreness in } \\
\text { urethra, urine scanty. } \\
\text { Modalities-Aggravated by warmth, touch and pressure; feels better in } \\
\text { open air, and cold bathing; }\end{array}$ & Apis 30 & $\begin{array}{l}\text { Twice daily for } 8 \text { days (at } \\
\text { least } 45 \text { minutes to I hr } \\
\text { before or after any food) } \\
\text { and Placebo for another } \\
22 \text { days }\end{array}$ & $\begin{array}{l}\text { Advised to report } \\
\text { after } 30 \text { days }\end{array}$ \\
\hline $18.04 .20 \mid 4$ & Improvement of her pain in the abdomen. & Placebo & I month & One month \\
\hline 20.05 .2014 & $\begin{array}{l}\text { Feeling of weakness gradually improving; urinary symptoms also } \\
\text { improved considerably. }\end{array}$ & Placebo & I months & $\begin{array}{l}\text { Advised to report } \\
\text { after } 30 \text { days }\end{array}$ \\
\hline 17.06 .2014 & $\begin{array}{l}\text { Right abdominal pain of moderate and bearable intensity with burning } \\
\text { feeling in the urethra, }\end{array}$ & Apis 200 & $\begin{array}{l}\text { Twice daily for } 2 \text { days, } \\
\text { with placebo for the rest } \\
28 \text { days }\end{array}$ & One month \\
\hline 21.07 .2014 & Felt mild pain in the abdomen once only otherwise doing well. & placebo & I month & One month \\
\hline 29.8 .2014 & $\begin{array}{l}\text { Presenting symptoms gradually improving, Status of patient further } \\
\text { improved and she continues to feel good with regular and normal } \\
\text { menstruation }\end{array}$ & placebo & I month & $\begin{array}{l}\text { Advised to report } \\
\text { after } 30 \text { days }\end{array}$ \\
\hline 24.09 .2014 & Profused bleeding with pain in abdomen. & Apis I M & $\begin{array}{l}2 \text { doses for } 2 \text { days, once } \\
\text { daily, rest } 28 \text { days placebo }\end{array}$ & One month \\
\hline
\end{tabular}


Table Continued..

\begin{tabular}{|c|c|c|c|c|}
\hline Visit & Symptoms & $\begin{array}{l}\text { Medicine } \\
\text { Given }\end{array}$ & $\begin{array}{l}\text { Period of taking } \\
\text { Medicine }\end{array}$ & $\begin{array}{l}\text { Advised to } \\
\text { Come after }\end{array}$ \\
\hline 23.10 .2014 & Doing well without any complaint. & placebo & One month & $\begin{array}{l}\text { one month, } \\
\text { Advised for } \\
\text { another USG }\end{array}$ \\
\hline $\begin{array}{l}\text { Final visit } \\
26.1 \text { I.20I4 }\end{array}$ & Reported vast improvement & $\begin{array}{l}\text { No medicine } \\
\text { prescribed }\end{array}$ & $\begin{array}{l}\text { Advised to report if any } \\
\text { problem occurs in future }\end{array}$ & $\begin{array}{l}\text { USG showed no } \\
\text { abnormality. } \\
\text { (Figure } 3 \& 4 \text { ) }\end{array}$ \\
\hline
\end{tabular}

Table 4 Details of symptom, prescriptions, and improvements of the Patient No. 3 (Age I6 years, unmarried)

\begin{tabular}{|c|c|c|c|c|}
\hline Visit & Symptoms & $\begin{array}{l}\text { Medicine } \\
\text { given }\end{array}$ & $\begin{array}{l}\text { Period of taking } \\
\text { medicine }\end{array}$ & $\begin{array}{l}\text { Advised to } \\
\text { come after }\end{array}$ \\
\hline $\begin{array}{l}\text { First Visit } \\
29.07 .2014\end{array}$ & $\begin{array}{l}\text { Right ovary shows a cyst extending into the Pouch of Douglas. Size not } \\
\text { mentioned. } \\
\text { General Symptoms: Severe pain in right lower abdomen, suppressed } \\
\text { menses and scanty also, with heaviness of right lower abdomen, stinging } \\
\text { pain; sense of tightness; bearing-down, as if menses were to appear; } \\
\text { abdomen sore and stinging pains, tenderness felt at perineum region; } \\
\text { leucorrhoea at onset of menstruation, frequently amenorrhoea for two or } \\
\text { three months; burning sensation during urination; burning and soreness in } \\
\text { urethra, and urine scanty. feels very tired, vertigo on closing eyes, craving } \\
\text { of milk, thirst less. } \\
\text { Modalities: Aggravated by warmth, touch and pressure; feels better in } \\
\text { open air, and cold bathing; }\end{array}$ & Apis 30 & $\begin{array}{l}\text { Twice daily for } 8 \text { days } \\
\text { (at least } 45 \text { minutes to } \\
\text { I hr before or after any } \\
\text { food) and Placebo for } \\
\text { another } 22 \text { days }\end{array}$ & $\begin{array}{l}\text { Advised to } \\
\text { yreport after } 30 \\
\text { days }\end{array}$ \\
\hline 25.08 .2014 & $\begin{array}{l}\text { Pain right abdomen gradually improving, feeling of weakness gradually } \\
\text { improving; urinary symptoms also improved considerably. }\end{array}$ & Placebo & I month & One month \\
\hline 21.09 .2014 & $\begin{array}{l}\text { Reappearance of right abdominal pain of bearable intensity with burning } \\
\text { feeling in the urethra, Menstrual flow normal last month. }\end{array}$ & Apis 200 & $\begin{array}{l}\text { Twice daily for } 2 \text { days, } \\
\text { with placebo for the } \\
\text { rest } 28 \text { days }\end{array}$ & One month \\
\hline 15.10 .2014 & $\begin{array}{l}\text { Symptoms that bothered her gradually improving, Status of patient } \\
\text { further improved and she continued to feel good with regular and normal } \\
\text { menstruation, no pain felt in this month. }\end{array}$ & placebo & I month & One month \\
\hline 16.11 .2014 & Reported painful and profuse bleeding in the last menstrual cycle. & Apis I M & $\begin{array}{l}2 \text { doses for } 2 \text { days, } \\
\text { once daily, rest } 28 \text { days } \\
\text { placebo }\end{array}$ & One month \\
\hline 19.12 .2014 & $\begin{array}{l}\text { Doing well without any undesirable symptoms. Advised to visit if any } \\
\text { symptom recurs. }\end{array}$ & placebo & One month & $\begin{array}{l}\text { one month, } \\
\text { Advised for } \\
\text { another USG }\end{array}$ \\
\hline $\begin{array}{l}\text { Final visit } \\
6.01 .2015\end{array}$ & No complaints till now and have not visited so far. & $\begin{array}{l}\text { No medicine } \\
\text { prescribed }\end{array}$ & $\begin{array}{l}\text { Advised to report if } \\
\text { any problem occurs in } \\
\text { future }\end{array}$ & $\begin{array}{l}\text { USG showed no } \\
\text { abnormality. } \\
\text { (Figure } 5 \& 6 \text { ) }\end{array}$ \\
\hline
\end{tabular}

Table 5 Hormonal parameters of each patient

\begin{tabular}{|c|c|c|c|c|c|c|c|c|}
\hline \multirow{2}{*}{ SI. No } & \multirow{2}{*}{ Blood parameter } & \multicolumn{2}{|c|}{ Pt. No - I } & \multicolumn{2}{|c|}{ Pt. No - 2} & \multicolumn{2}{|c|}{ Pt. No - 3} & \multirow[t]{2}{*}{$\begin{array}{l}\text { Significant level between } \\
\text { BM vs.AM }\end{array}$} \\
\hline & & BM & AM & BM & $\mathbf{A M}$ & BM & AM & \\
\hline $\mathrm{I}$. & $\mathrm{LH} \mathrm{mlU} / \mathrm{ml}$ & 15.04 & 5.05 & 16.50 & 5.25 & 17.56 & 7.56 & $* * *$ \\
\hline 2. & $\mathrm{FSH} \mathrm{mlU} / \mathrm{ml}$ & 4.70 & 4.90 & 4.55 & 4.15 & 6.55 & 7.16 & NS \\
\hline 3. & LH:FSH Ratio & $3.2: 1$ & I.03:I & $3.62: 1$ & $1.26: 1$ & 2.68:I & I.05:1 & $* * *$ \\
\hline 4. & S. Free Testosterone $\mathrm{pg} / \mathrm{ml}$ & 4.7 & 3.05 & 4.25 & 4.60 & 5.47 & 3.25 & $*$ \\
\hline 5. & DHEAS $\mu \mathrm{g} / \mathrm{ml}$ & 180.22 & 189.06 & 206.58 & 210 & 201.23 & 195.22 & NS \\
\hline 6. & Prolactine $\mathrm{ng} / \mathrm{ml}$ & 12.89 & 11.90 & 9.15 & 10.20 & 12.36 & 9.02 & NS \\
\hline 7. & $\mathrm{E}_{2} \quad($ Estradiol $) \mathrm{pg} / \mathrm{ml}$ & 209.34 & 250.08 & 150.22 & 187.88 & 187.02 & 201.53 & NS \\
\hline 8. & Insulin $(F) \mu \mathrm{lU} / \mathrm{ml}$ & 12.87 & 14.65 & 8.20 & 8.75 & 14.25 & 9.25 & NS \\
\hline 9. & Insulin (PP) $\mu \mathrm{lU} / \mathrm{ml}$ & 90.55 & 82.44 & 100.03 & 96.45 & 95.22 & 89.25 & NS \\
\hline 10. & Glucose $(F)$ mg/dl & 105.87 & 92.14 & 96.47 & 90.46 & 110.21 & 105.25 & NS \\
\hline
\end{tabular}




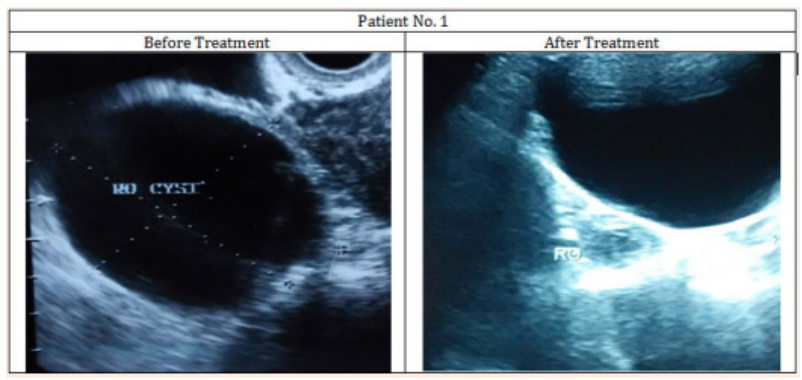

Figure I Images of Ultra-sonography of the patient No. I showing removal of the cyst from right ovary.

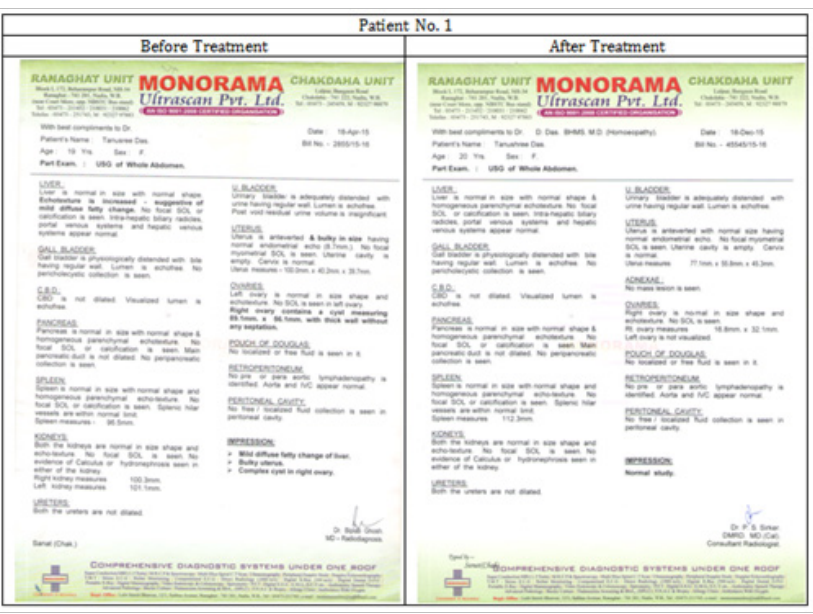

Figure 2 Ultra-sonographic reports of the patient No. I showing removal of the cyst from right ovary.

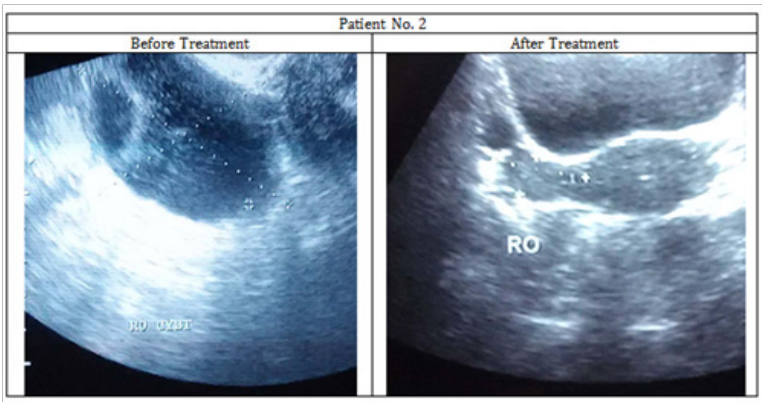

Figure 3 Images of Ultra-sonography of the patient No. 2 showing removal of the cyst from right ovary.

\section{Results and discussion}

From analysis of the change in ameliorating symptoms or recurrence of unwanted symptoms, the suitable potencies were prescribed; initially all three patients received the $30 \mathrm{C}$ potency and advised to come after one month. In all the patients, amelioration of symptoms like irregularity of menstruation, reduction in intensity of pain was noticed after administration of the $30 \mathrm{C}$ potency to a varying degree. Whenever there was a recurrence of symptoms after a period of steady amelioration, the next higher potency was chosen. And when all the symptoms were totally gone gradually, the final USG was advised for checking whether the cysts had also been removed. In all the patients, USG revealed presence of the cysts before drug administration, but finally in all the cases there was no more any trace of the cysts.

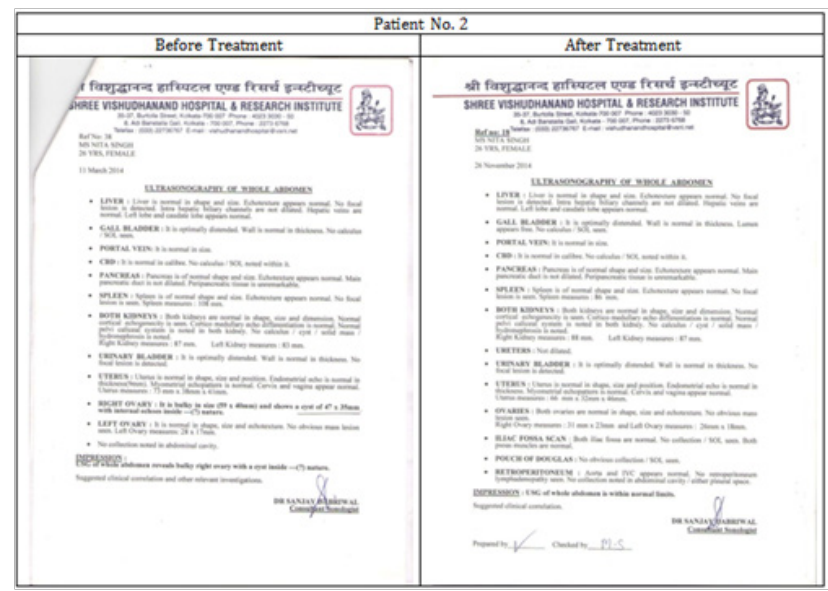

Figure 4 Ultra-sonographic reports of the patient No. 2 showing removal of the cyst from right ovary.

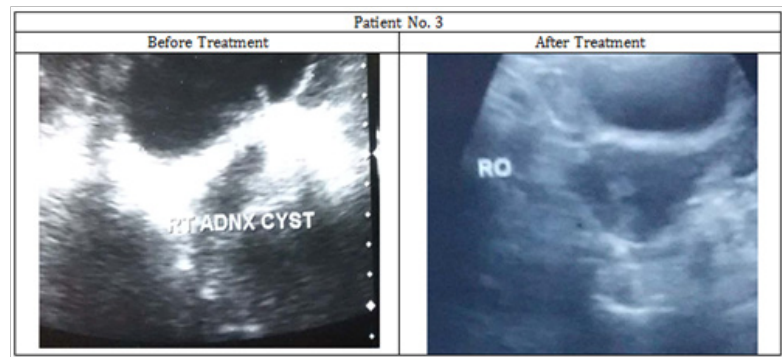

Figure 5 Images of Ultra-sonography of the patient No. 3 showing removal of the cyst from right ovary.

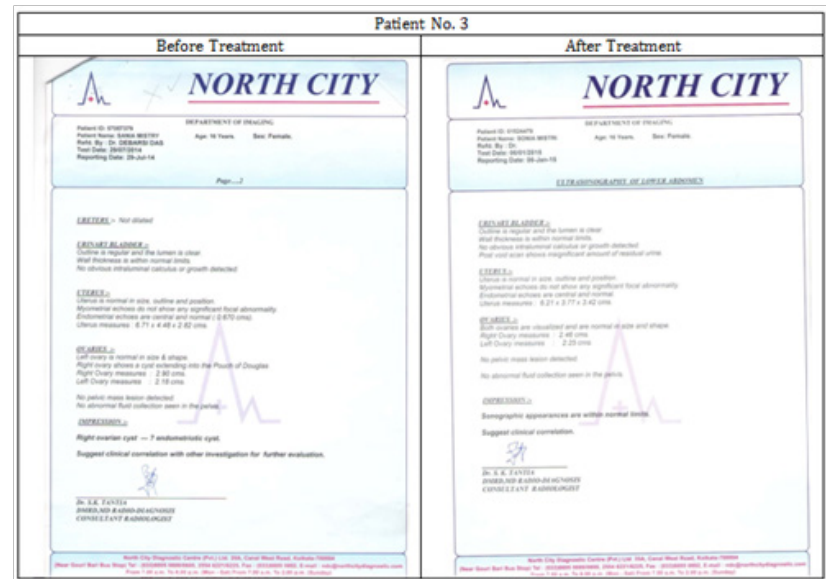

Figure 6 Ultra-sonographic reports of the patient No. 3 showing removal of the cyst from right ovary.

In order to correlate if hormonal activities in the patients during the treatment were also modulated we advised the patients to check up if there were any hormonal changes associated with the abolition of the cysts. The data in respect of certain probable hormones known to be associated with the formation/removal of cysts were therefore also recorded, both prior to and after completion of drug administration. The results of changes of the different important hormones have been enlisted in Table 5 and represented in the bar diagrams to show if the changes were statistically significant (Figure 7). An appraisal of the data would reveal that significant changes in the important hormones like LH (highly significant $\mathrm{p}<0.001)$, LH/FSH ratio $(\mathrm{p}<0.001)$, 
and pre-testosterone $(\mathrm{p}<0.05)$ occurred during the period of drug administration to the end of the treatment period. These hormonal changes are significant in that the lower level of LH as well as the LH/ FSH ratio are considered favourable factor for promoting fertility and other associated phenotypic problems. ${ }^{8}$ Apart from these remarkable changes, there were also indication of favourable changes in certain hormones like estradiol, prolactin, DHEAS and insulin (both fasting and $\mathrm{pp}$ ) although these changes were statistically insignificant. The glucose level for both fasting and $\mathrm{pp}$ in all the patients were favourably modulated, though they did not show statistical significance, partly because of the range which is considered normal for a person varies (eg. between 80 and $110 / 120 \mathrm{mg} / \mathrm{dl}$ ). Similarly all the symptoms had almost gone away in all three patients and their final USG also confirmed removal of their cysts.

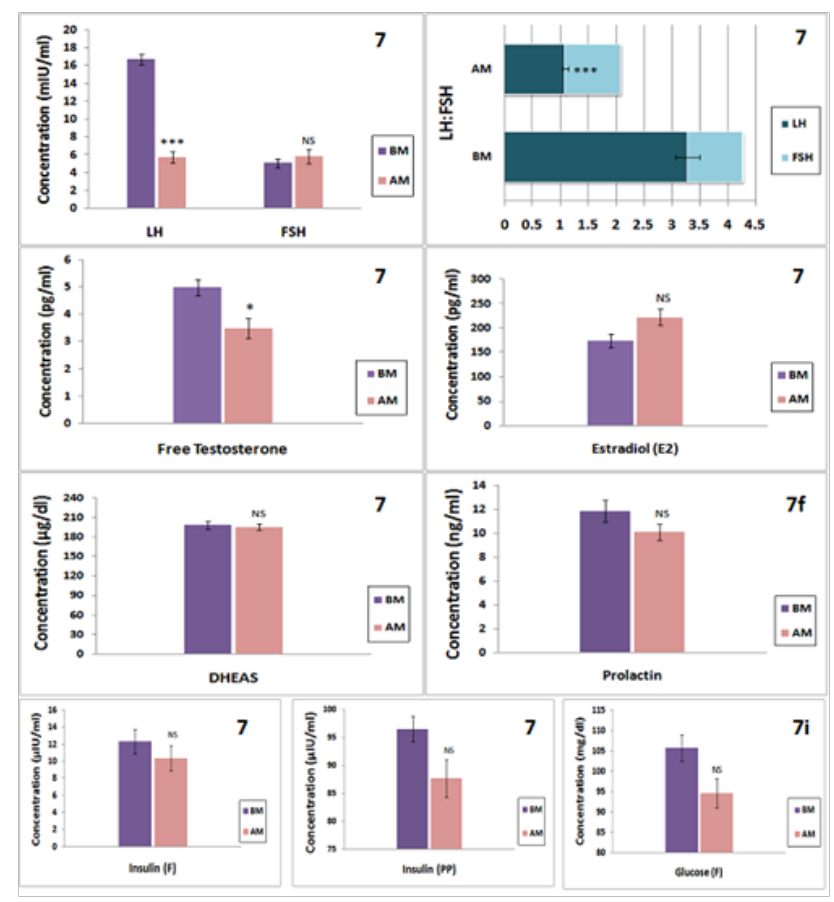

Figure 7 Graphical representations of hormonal parameters.

\section{Conclusion}

In conclusion, the results of the present study would indicate that proper selection of the homeopathic remedy matching the totality of symptoms and in consultation with the Kent's rubric ${ }^{4}$ can remove cysts from the ovary without any surgical intervention and this can serve as an alternative option, at least in patients where surgery also has some risk or undesirable. This can curtail cost of treatment for the economically under-privileged section of the people as well, particularly residing in remote areas where medical amenities and infra-structural facilities for doing surgery are by and large are still unavailable. ${ }^{9}$

\section{Acknowledgements}

DD conveys his gratitude to the Principal, Bengal Homeopathic Medical College and Hospital, Asansol, to the Principal of Mahesh Bhattacharyya Homeopathic Medical College and Hospital, Howrah and to the WB University of Health Sciences for allowing him to carry out this work as a part of his Ph.D programme. ARK-B is thankful to UGC for awarding Emeritus Fellowship to him.

\section{Conflicts of interest}

Author declares there are no conflicts of interest.

\section{Funding}

None.

\section{References}

1. OWH. Ovarian cysts. 2015.

2. Benifla JL, Hauuy JP, Guglielmina JN, et al. Celioscopic removal of cysts: a fortuitous histological discovery of an ovarian carcinoma. A case report. J Gynecol Obstet Biol Reprod. 1992;21(1):45-49.

3. Renolleau C, Daraï E, Madelenat P, et al. Laparoscopy and ovarian cancer: dangers and precautions. Contracept Fertil Sex. 1997;25(9):510.

4. Allen HC. Keynotes and characteristics with comparisons of some of the leading remedies of the Materia Medica with nosodes. (2nd edn), B Jain Publishers Pvt. Ltd., New Delhi, India. 2002.

5. Boericke W. Pocket Manual of Homoeopathic Materia Medica \& Repertory: Comprising of the Characteristic and Guiding Symptoms of All Remedies (clinical and Pahtogenetic [sic]) Including Indian Drugs. 2nd edn. Jain Publishers (P) Ltd., New Delhi, India. 2002.

6. Kent JT. Lectures on Homeopathic Materia Medica: Together withKent's "new Remedies" Incorporated and Arranged in One Alphabetical Order. 2nd edn. B Jain Publishers Pvt. Ltd., Noida, India. 1985.

7. Das D, Das I, Das J, et al. Efficacy of two traditionally used potentized homeopathic medicines, Calcarea carbonica and Lycopodium clavatum, used for treating PCOS patients: I. Effects on certain important external guiding symptoms. TANG [HUMANITAS MEDICINE]. 2016;6(1):1-6.

8. Das D, Das I, Das J, et al. Efficacy of two commonly used potentized homeopathic drugs, Calcarea carbonica and Lycopodium clavatum, used for treating polycystic ovarian syndrome (PCOS) patients: II. Modulating effects on certain associated hormonal levels. TANG [HUMANITAS MEDICINE]. 2016;6(1):1-7.

9. Banaszewska B, Spaczyński RZ, Pelesz M, et al. Incidence of elevated LH/FSH ratio in polycystic ovary syndrome women with normo- and hyperinsulinemia. Rocz Akad Med Bialymst. 2003;48:131-134. 